\title{
Tarımsal Katma Değer Belirleyicilerinin Panel Veri Analizi ${ }^{1}$
}

\author{
Zeynep ERDiNÇ² - Gökçen AYDINBAŞ³
}

Başvuru Tarihi: 24.12 .2020

Kabul Tarihi: 05.02.2021

Makale Türü: Araştırma Makalesi

\section{Öz}

Bu çalışmanın amacı, seçilmiş 20 ülkenin Dünya Bankası ve Dünya Genelinde Yönetişim Göstergeleri sitelerinden elde edilen 2000-2018 dönemine ait yıllı verileriyle tarımsal katma değer ve belirleyicilerinin panel veri analiz yöntemi kullanılarak incelenmesidir. Analizde; sabit etkiler modeli, rassal (tesadüfi) etkiler modeli, genelleştirilmiş momentler yöntemi (GMM), sistem GMM ve robust (dirençli hata) tahmincileri ekonometrik modelleri kullanılmıştır. Panel veri yöntemi kapsamındaki analiz sonuçlarına göre bağımlı değişken olan tarımsal katma değer ile arasında pozitif yönlü ve anlamlı bir ilişki saptanan bağımsız değişkenler; kişi başına GSYH, brüt sabit sermaye oluşumu, tarımsal işgücü oranı (toplam işgücü \%) ve kentleşme oranı (toplam nüfus \%) olmuştur. Tarımsal katma değer ile arasında anlaml fakat negatif yönde bir ilişki tespit edilen bağımsız değişken ise hukukun üstünlü̆̈̈̈ endeksi olmuştur. Ayrıca tarımsal katma değer ile bağımsız değisskenlerden politik istikrar endeksi arasında istatistiksel olarak anlamlı bir ilişki saptanamamıştır.

Anahtar Kelimeler: Tarımsal Katma Değer, GSYH, Panel Veri Analizi

Atıf: Erdinç, Z. ve Aydınbaş, G. (2021). Tarımsal katma değer belirleyicilerinin panel veri analizi. Anadolu Üniversitesi Sosyal Bilimler Dergisi, 21(1), 213-232.

\footnotetext{
${ }^{1} \mathrm{Bu}$ çalışma etik kurul izin belgesi gerektirmemektedir.

${ }^{2}$ Anadolu Üniversitesi İktisadi ve İdari Bilimler Fakültesi İktisat Bölümü, zerdinc@anadolu.edu.tr, ORCID: 0000-0001-9599-0630

${ }^{3}$ Anadolu Üniversitesi Sosyal Bilimler Enstitüsü İktisat Bölümü Doktora Öğrencisi, gokcen_a@anadolu.edu.tr, ORCID: 0000-0001-9435-5387
} 


\title{
Panel Data Analysis of Value-Added Agriculture Determinants
}

\author{
Zeynep ERDiNÇ⿻ - Gökçen AYDINBAŞ
}

\begin{abstract}
The aim of this study is to investigate the value-added agriculture and its determinants using the panel data analysis method with annual data of 20 selected countries for the period 2000-2018 obtained from the World Bank (WB) and Worldwide Governance Indicators (WGI) websites. In the analysis; fixed effects model, random effects model, the generalized method of moments (GMM), system GMM and robust (resistive error) estimators econometric models were used. As a result of the analysis, made within the scope of panel data method, independent variables which have a significant and positive relationship with as a dependent variable valueadded agriculture were GDP per capita, gross fixed capital formation, the agricultural labor force rate (\% of total labor force) and the rate of urbanization (\% of total population). The independent variable that has a significant but negative relationship with value-added agriculture is rule of law index. In addition, there was no statistically significant relationship between value-added agriculture and political stability index"as the independent variable".
\end{abstract}

Keywords: Value-Added Agriculture, GDP, Panel Data Analysis

\footnotetext{
4 Anadolu University Faculty of Economics and Administrative Sciences Department of Economics, zerdinc@anadolu.edu.tr, ORCID: 00000001-9599-0630

5 Anadolu University Graduate School of Social Sciences Department of Economics (Student), gokcen_a@anadolu.edu.tr, ORCID: 0000-00019435-5387
} 


\section{Giriş}

İnsanlık tarihindeki üç önemli devrimden ilki olan tarım devrimi, yerleşik hayata geçişle beraber ortaya çıkmıştır. İkinci olarak buhar gücünün makinelerde kullanımıyla sanayi devrimi başlamış, son olarak bilgi toplumuna geçilerek üçüncü devrim meydana gelmiştir. Bu devrimlerle birlikte gücüne güç katan tarım ve sanayi arasındaki karşılıklı bağımlılık giderek artmıştır. Buna bağlı olarak, tarım sektörü geliştikçe sanayi sektörü gelişmekte, sanayi sektörü büyüdükçe tarım sektörünü desteklemekte, sanayi sektöründeki duraksama ise tarım sektörünü etkilemektedir. Nitekim arzulanabilir bir şekilde dengeli ekonomik kalkınma için, bu sektörler arasında olumlu etkileşimlerin olması gerekmektedir.

Teknolojinin gelişimiyle tarımın, gerek sanayi gerekse hizmetler sektörünün etkisi doğrultusunda milli gelirdeki payı oldukça önemli hale gelmiştir. Bir ülke ve toplumun kalkınmasında kilit unsurlardan biri olan tarım sektörünün; ekonomik sistemin küreselleşmesi, rekabet ortamlarındaki artış ve pazar koşullarının hızlıca değişmesine bağlı olarak zamanla önemi artmaktadır.

Bu çalışma kapsamında, 2000-2018 dönemi için 20 ülke bazında (Brezilya, Türkiye, Fransa, Amerika Birleşik Devletleri, İngiltere, Endonezya, Malezya, Rusya, Almanya, Çin, Avustralya, Hindistan, Güney Afrika, İtalya, İspanya, Meksika, Hollanda, Japonya, Nijerya, Romanya) tarımsal katma değer belirleyicilerini panel veri analiz yöntemiyle tespit etmek amaçlanmıştır. Tarımsal ürün katma değer belirleyicileri olarak kişi başına gayrisafi yurtiçi hasıla (GSYH), brüt sabit sermaye oluşumu, tarımsal işgücü oranı (toplam işgücü\%), kentleşme oranı (toplam nüfus\%), politik istikrar ve hukukun üstünlügü endeksi serileri alınmıştır. Analiz sonucunda elde edilen tahminler ile kişi başına gayrisafi yurtiçi hasıla (GSYH), brüt sabit sermaye oluşumu, tarımsal işgücü oranı (toplam işgücü\%), kentleşme oranı (toplam nüfus\%), politik istikrar ve hukukun üstünlüğü endeksinin tarımsal ürün katma değerini nasıl etkilediği değerlendirilmiştir.

Çalışmanın literatürdeki diğer çalışmalardan farklı yönü, kategorilere ayrılarak kullanılan çeşitli değişkenler bazında tarımsal katma değerin belirleyicilerinin saptanmasıdır. Tarımsal katma değerin etkilenebileceği değişkenler; ekonomik, sosyal, siyasi ve hukuki çerçevede ele alınmıştır. Bu değişkenlerin tarımsal katma değer üzerindeki etkileyici gücünün tespitiyle katma değeri arttırıcı yönde gelişmelere odaklanılarak ekonomik büyümeye katkı sağlanmakta, bu da ülke refahını yükseltmektedir. Tam da bu noktada, farklı boyutların değerlendirilmiş olduğu bu çalışmanın, diğerlerini tamamlayıcı nitelikte olduğu ve literatüre önemli katkılar sunacağı düşünülmektedir.

Çalışmada öncelikle, tarımsal katma değeri belirleyen faktörlerin teorik olarak ele alınması ile dünya genelinde ve Türkiye özelinde tarım sektöründeki gelişmelere değinilmiştir. İkinci olarak, ampirik literatür çerçevesinde tarımsal katma değeri etkileyen faktörlerden söz edilmiştir. Daha sonra, ampirik analizde kullanılan yöntem, veri seti ve modeller incelenerek araştırma bulguları yorumlanmıştır. Ardından da bulgulara ilişkin bir değerlendirmeye sonuç kısmında yer verilerek çeşitli politika önerileri sunulmuştur.

\section{Tarımsal Katma Değer Belirleyicileri: Teori ve Ampirik Literatür}

Tarımsal faaliyetler, insanoğlunun yaşamını sürdürebilmesi için gerçekleştirilmektedir. İnsanın temel gereksinimiyle alakalı olan bu faaliyetler; sanayiye hammadde, sermaye ve gıda sağlamaktadır. Nitekim Maslow'un ihtiyaçlar Hiyerarşisi Teorisi'nin birinci basamağında gıdanın bulunduğu bilinmektedir. Burada gıda ihtiyacı karşılandığı sürece üst basamaklara geçişin mümkün olacağı, dolayısıyla tarımın bir ülkedeki insanların gıda ihtiyacını karşılayan bir sektör olduğu teorik açıdan kanıtlanmıştır (Erkuş vd., 2005).

Ülke ekonomisinin temelini oluşturan tarım sektörü; besin maddelerinin üretilip işlenerek çeşitlendirilmesi ile insanların bu maddelere yönelik ihtiyaçlarının giderilmesi açısından toplum sağlığı ve kalkınmasına bir katkı sunmaktadır. Bir başka ifadeyle sosyo-ekonomik bağlamda toplum sağlığı; kalkınma, yeterli ve dengeli 
beslenmeyle sağlanabilmektedir. Dolayısıyla insanoğlunun hayatına devam edebilmek adına beslenme ihtiyacını iyi bir şekilde karşılaması gerekmektedir. Kapsamlı olarak düşünüldügünde tarım, bitkisel ve hayvansal üretimle ormancılık ve su ürünlerinin kalite ve verimliliğinin yükseltilmesi, uygun koşullarda korunması, işlenmesi ve pazarlanması olarak tanımlanabilmektedir (Olalı ve Duymaz, 1987, s. 3). Bir başka deyişle tarım, hayvansal ve bitkisel varlıkların, topluma besin maddeleri/hammadde sağlamak adına biyolojik açıdan üretim kabiliyetlerinin planlayarak ve yönlendirerek kullanmak anlamına gelmektedir. Tarım sektörü, beslenme açısından gerekli hayvansal ve bitkisel gıda maddeleri ihtiyacının karşılanmasının yanı sıra endüstriyel üretime gerekli hammaddenin temini vasıtasıyla ülke ekonomisine katma değer kazandırmaktadır. Katma değer, üretilen mal ve hizmetlerin parasal değeriyle üretimde kullanılan girdiler arasındaki farkı temsil etmektedir. Makro açıdan tarımsal katma değer, tarım sektöründeki çıktıların toplamıyla girdiler arasındaki farkın sonucunda ulaşılan rakamsal olarak net üretimi ifade etmektedir. Birleşik Devletler Tarım Departmanı (USDA)'nın yaptığı tanıma göre tarımsal katma değer, üretilmiş olan tarım ürünün fiziki durumuyla birlikte maddi değerinde bir ilerleme sağlamak anlamına gelmektedir (Lu \& Dudensing, 2015, s. 1-2). Nitekim ülkeler, milli geliri oluşturan katma değeri yükseltme amacı doğrultusunda çabalamaktadır. Yaratılan katma değerin yüksek olmasına bağlı olarak üretilen ürünün ülke içinde tüketimi mümkün olmakta, ürüne yönelik yapılan harcamalar da ülke içerisinde kalmaktadır. Son yıllarda, tarımsal üretim kapsamında geçmişe kıyasla yoğun olarak modern girdi ve teknoloji kullanılmaktadır. Bu doğrultuda elde edilen tarımsal ürünlerin, çeşitli işlemlerden geçmesiyle yurt içi ve yurt dışındaki tüketicilere ulaştırılması söz konusu olmaktadır (Çetin, 2010, s. 24).

Günümüzde tarımsal açıdan sürdürülebilir tarım ve organik tarım, öne çıkan kavramlar olarak belirmiştir. Sürdürülebilir tarım; gıda, doğal kaynak ve enerji gereksinimini karşılamakla birlikte toprak, su ve biyolojik çeşitliliği korumakta olan bir uygulamayı ifade etmektedir (Menalled vd., 2008). Bir başka ifadeyle sürdürülebilir tarım, insan sağlğ̆ı ve çevre koruyucu üretim sistemlerinin yanı sıra dengeli teknoloji kullanımı ve işletmelerin düzgün bir şekilde yönetilmesini içeren sistemlerin tümü olarak tanımlanabilmektedir. Organik tarım ise; ekolojik çeşitliliğin korunması temelli ve insana ve çevre dostu üretim sistemi odaklı sürdürülebilir bir tarım sistemi olarak tanımlanmaktadır. Bir başka deyişle organik tarım, sosyo-ekonomik ve çevresel bazda sürdürülebilir, bütünleşmiş bir tarım sistemi kurmayı amaçlayan tarımsal bir yaklaşımı ifade etmektedir (Lampkin, 1990). Organik tarım kapsamında uygulamalar gelişmiş ve gelişmekte olan ülkelerde yaygınlıkla görülmeye başlanmıştır. Organik tarım öncelikle Avrupa ve Amerika Birleşik Devletleri (ABD)'nde başlayıp zamanla diğer ülkelere de geçmiştir. Türkiye'de, Avrupalı ithalatçıların talepleri üzerine 1980'li yılların ortasında Ege Bölgesi'nde başlamıştır. Organik tarım kapsamında kullanılan bütün gıda/besin maddeleri, barınma ve giyim maddelerinin insan sağlığına zarar vermeyecek veya minimum zarar verecek şekilde ve sürekli üretimi amaçlanmaktadır. Organik tarım; erozyon, çölleşme, iklim değiişikliğine yol açan unsurların etkisinin giderilmesinde temel bir kaynak olup kimyasal kirlilik ve zehirli kalıntının sonlandırılmasını hedef olarak benimsemiştir (Gündüz ve Kaya, 2007, s. 315-316).

\section{Dünyada ve Türkiye'de Tarım Sektörü}

Sosyo-ekonomik ve çevresel boyutları hesaba katıldığında tarım sektörü, gelişmişlik düzeyi ne olursa olsun tüm ülkeleri/toplumları yakından ilgilendiren bir olgudur. Bunun nedeni tarımın; bir ülkedeki insanların yaşamsal faaliyetlerini devam ettirebilmesi, milli gelir/istihdam doğrultusunda kazanç sağlaması, diğer sektörlere sermaye ve hammadde temin etmesi, ihracata yönelik doğrudan ve dolaylı tesiri ve gerek biyolojik çeşitlilik gerekse ekolojik denge kapsamındaki desteğinden ötürü bütün dünya için elzem bir sektör niteliğinde olmasıdır. Endüstri Devrimi ile birlikte dünyanın tarımla uğraşan nüfusu azalmış, insanoğlu hizmet ve mamul mal üreticisi durumuna gelmiştir. Dolayısıyla üretim biçimleri de bu doğrultuda yeniden şekillenmiştir. 
Tarih boyunca ırklara göre tarım, birbirinden farklı şekillerde gerçekleşmiştir. Eski Roma ve Yunanlarda tarım zenginlik kaynağı olurken, Ortaçağ’da ise üretimin başlaması ve paranın oluşumuna paralel olarak farklı biçimde değerlendirilmiştir (Torun, 2003, s. 181). Dünyada tarım sektöründe yaşanan önemli gelişmeler; İngiliz çiftçilerin geliştirdiği dörtlü ekim nöbeti sistemi (sistemin faydası; buğday, şalgam, arpa, yonca ekimiyle tarımsal verimlilikte artış), Alman kimyacı Justos Liebig'in 1840 yılında fosfor, azot ve potasyumun bitkilerin gelişmesini olumlu etkilemesinin tespitiyle yapay gübre icadı (bununla birlikte verimlilik artışı ve ekonomik bir güç oluşturması) olarak belirtilebilmektedir. Türkiye ise, tarihsel süreçte farklı uygarlıkları barındırmış bir coğrafyada yer almaktadır. Bu uygarlıklarda tarımsal faaliyetler, bölgesel açıdan iklimin farklılaşması ve Anadolu'nun eski bir dünya merkez olması sebebiyle çeşitli şekillerde yapılmıştır. Söz konusu uygarlıklardan en önemlileri; Asur, Hitit, Bizans, Selçuklu ve Osmanlı İmparatorluğu'dur (Doğan, Berkman ve Arslan, 2015, s. 32). Osmanlı İmparatorluğu'nda tarım, gerek ekonomik gerekse askeri gücü koruyabilmek adına büyük bir sorumluluk almıştır. Türkiye Cumhuriyeti'nin kuruluşunun ilk dönemlerinde kırsal nüfus toplam ülke nüfusunun \%80'ini teşkil ederken, söz konusu nüfusun \%90'nın da tarımsal faaliyetlerde bulunması, tarımın önemini kanıtlamaktadır. 1927 yılında yapılan ilk tarım sayımında, ülkenin tarımsal durumunun belirlenmesi amaçlanmıştır. Ancak, Cumhuriyet döneminde tarıma ilişkin dönüm noktalarından en önemlisi, 1980 yılında yaşanan dışa dönük büyüme stratejisi (ithal ikameci sistemden vazgeçilmesiyle) olmuştur (Bilgen ve Çılbant, 2015, s. 687-688).

Günümüze kadar ülkelerin sosyo-ekonomik açıdan gelişmesinde oldukça önemli görevlerdeki tarım sektörünün, gelecekte de bu görevleri üstlenmeyi sürdüreceği düşünülmektedir. Dünyada sanayi (endüstri) 4.0 ile beraber "dijital tarım" ya da "tarım 4.0" olarak nitelendirilen yeni bir kavram ortaya çıkmıştır. Hassas çiftlik üretim sistemi temelli tarım mühendisliği evrimi olan "tarım 4.0 (dijital tarım)"da amaç, tarımda sürdürülebilir üretim otomasyonunu sağlamaktır. Tarım 4.0; "robotlar, dronlar, dikey çiftlikler, yapay zeka, nesnelerin interneti ve güneş enerjisi”nin kullanımını mümkün kılmaktadır. Dijital teknolojilerin tarım sektörüne uyarlanması; ürün verimliliğinde artışı, maliyette azalmayı, ürün kaybının azalmasını, su/yakıt/gübrenin minimum kullanımını sağlamaktadır. Türkiye gibi çok fazla bitki çeşitliliğine sahip, az sayıda ülke bulunmaktadır ki bu bakımdan tarım 4.0'ın Türkiye'de uygulanması büyük önem taşımaktadır (Kilavuz ve Erdem, 2019. s. 136-148).

\section{Dünya ekonomisinde tarım}

Dünyada tarımsal üretimin teknolojik imkânlar doğrultusunda arttırılması, bu üretim artışının belli bir düzeyden sonra sınırlı kalması ve gittikçe artan tarımsal ürün talebini karşılayamaması durumu, tarımsal potansiyele sahip ülkeler için önemli bir kazanç kapısı oluşturmuştur (Erçakar ve Taşçı, 2011, s. 183). Tarım sektörü, sanayileşme sürecini tamamlayamamış toplumlar için bir firsata dönüşmüştür. Gelişmekte olan ülkelerde tarım sektörünün nitelikleri; tarımsal üretimin istihdamını oluşturma ve diğer sektörlere yönelik sermaye birikimi kaynağı olma, tarımsal ürün ihracatıyla döviz kazandırma şeklinde sıralanmaktadır (Garcia, 1981, s. 12). Bu bakımdan görülen şudur ki; gelişmekte olan ülkelerde tarımsal üretim kapsamında yapılan uygulamaların iyileşmesi söz konusudur. Ekonomik kalkınma sürecinde; tarım-sanayi ilişkisinin ve etkileşiminin güçlü olduğu bilinmektedir. Eskiden tarıma dayalı ekonomileri olan gelişmiş ülkeler, tarım sektöründe sağladıkları kaynak birikimleri sayesinde hızlı bir şekilde sanayileşmeye başlamıştır. Sanayileşmenin finansmanını tarımdan elde ettikleri kaynaklarla sağlayan ülkeler; Fransa, İngiltere, Rusya ve Japonya'dır (Doğan, Berkman ve Arslan, 2015, s. 34).

Dünyadaki toplam mal üretimi 2012 verilerine göre; 72.25 milyar ABD doları iken, bunun \%4,2'si "3.029 milyarlık kısma” tekabül eden tarımsal ürün üretimidir. Tarımsal ürünlerin \%55’i "1.656 milyar dolarlık kısmı" tarımsal ürün ihracatını teşkil etmektedir. Dolayısıyla ülkeler bazında ekonomik katkıları açısından değerlendirildiğinde sektörün, istihdam sağlayıc1/ticari etkisi dikkat çekmektedir. 2008-2018 yıl aralığında, küresel krizlerin olumsuz etkileri devam ettiği halde tarımsal ürün ihracatı \%35 oranında artmıştır (Dünya 
Ticaret Örgütü, 2019). Ancak son yıllarda, tarımsal katma değerin gayri safi yurtiçi hasıladaki payının giderek azaldığını söylemek mümkündür. Dünya Bankası 2018 yılı verilerine göre; tarım, orman ve balıkçlık katma değerinin GYSH içindeki payı 1997 yılında \%14.46 iken, 2000 yllında \%10.08 ve 2016 yılında \%6,18 oranında seyretmektedir (Petek ve Şanlı, 2019, s. 54).

Tablo 1

Ülkeler Bazında Tarımsal Katma Değer (2012-2015)

\begin{tabular}{lcrrrrrrr}
\hline & \multicolumn{2}{c}{$\mathbf{2 0 1 2}$} & \multicolumn{2}{c}{$\mathbf{2 0 1 3}$} & \multicolumn{2}{c}{$\mathbf{2 0 1 4}$} & \multicolumn{2}{c}{$\mathbf{2 0 1 5}$} \\
\hline \multirow{3}{*}{ Ülkeler } & TKD & TKD/ & TKD & TKD/ & TKD & TKD/ & TKD & TKD/ \\
& (Milyon & Toplam & (Milyon & Toplam & (Milyon & Toplam & (Milyon & Toplam \\
& ABD & GSYH & ABD & GSYH & ABD & GSYH & ABD & GSYH \\
& Doları) & & Doları) & & Doları) & & Dolar1) & \\
\hline Hindistan & 309.289 & 18.2 & 326.518 & 18.6 & 325.898 & 18 & 328.143 & 17.5 \\
Çin & 632.771 & 9.4 & 656.896 & 9.3 & 683.575 & 9.1 & 710.254 & 8.3 \\
Rusya & 57.542 & 3.7 & 60.147 & 3.6 & 61.059 & 4.1 & 62.817 & 4.6 \\
Endonezya & 114.344 & 13.7 & 119.151 & 13.7 & 124.202 & 13.7 & 128.880 & 13.9 \\
ABD & 148.044 & 1.2 & 176.751 & 1.4 & 175.544 & 1.3 & 180.726 & 1.1 \\
Pakistan & 43.638 & 24.5 & 44.806 & 24.8 & 45.924 & 24.9 & 46.903 & 25.1 \\
Brezilya & 93.076 & 4.9 & 100.858 & 5.3 & 103.673 & 5 & 107.415 & 5 \\
Japonya & 63.946 & 1.1 & 64.132 & 1.1 & 62.002 & 1 & 56.515 & 1.1 \\
Nijerya & 95.341 & 22 & 98.141 & 21 & 102.332 & 20.2 & 106.137 & 20.9 \\
Türkiye & 73.648 & 8.8 & 75.356 & 7.7 & 75.803 & 7.5 & 82.908 & 7.8 \\
\hline Kayna & & & & & & & &
\end{tabular}

Kaynak: Dünya Bankası (World Bank).

Tabloya göre; Endonezya, Pakistan ve Rusya dışındaki ülkelerde yıllara göre tarımsal katma değerin GSYH'deki payı azalmaktayken, katma değerin dolar cinsinden artışı gözler önüne serilmektedir (Tablo 1). Şunu söylemek mümkündür ki; tarımsal üretimin katma değer artışı açısından nicelikten daha çok niteliği öne çıkmaktadır.

Doğal koşullardan oldukça kolay etkilenen tarım sektörü, dünyada gerçekleşen ekonomik dalgalanmalardan ötürü birtakım olumsuzluklara maruz kalabilmektedir. Örneğin, dünyada yaşanan ekonomik dalgalanmalara bağlı olarak çoğu tarımsal mamulde fiyat artışları gerçekleşmiştir. Birleşmiş Milletler (BM) raporları kapsamında; tarımsal mamullerdeki fiyat artışlarının süregelmesiyle ileride öncelikle Afrika Kıtası ile birlikte çoğu üçüncü dünya ülkesinin gıda problemleriyle karşılaşacağı, Afrika Kıtası'nın 2025 yılında 1 milyarı aşkın nüfusunun yalnızca \%25'ini besleyebilecek düzeyde bulunacağı öngörülmektedir (Doğan, Berkman ve Arslan, 2015, s. 32). Bu sebeple Birleşmiş Milletler Gıda ve Tarım Örgütü (FAO) tarafından belirtildiği üzere, 2050 yllında küresel nüfusun 10 milyar kişiye yaklaşmasıyla söz konusu nüfusu doyurmak için üretimde \%70'lik bir artış gerçekleştirilerek gerekli gıda güvenliğinin ve/veya güvencesinin oluşturulması, tarım sektörünün daha üretken ve/veya verimli olmasını gerektirmektedir (Gökırmaklı ve Bayram, 2018, s. 352).

\section{Türkiye ekonomisinde tarım}

Farklı iklim kuşaklarına birlikte ev sahipliği yapan Türkiye; üç tarafının denizlerle (Ege, Karadeniz ve Akdeniz) kaplı olması, jeopolitik konumu, akarsuları ve ekolojik çeşitliliğiyle hem hayvansal ve bitkisel hem de su ürünlerinde oldukça önemli bir ülkedir. Bir başka ifadeyle Türkiye ekonomisinde tarım; "istihdam, nüfus, tarımsal üretim, beslenme, tarımın sanayiye katkısı, yurt içi tüketim, ödemeler dengesi ve milli gelir" bakımından oldukça önemli bir sektördür (Kan, 2019, s. 53). 
Cumhuriyetin ilk yılları itibariyle Türkiye'de tarım sektörü ulusal ekonomi açısından, öncelikle gelir, istihdam, dış ticaret ve pazara yönelik önemli katkılar sunmuştur (Olgun ve Işın, 2018, s. 64). 1950’li yıllarda Marshall yardımlarıyla Türkiye'de tarımda makineleşmenin hız kazanması, tarımsal işgücü ihtiyacını düşürmüştür. Türkiye'de sanayiye yönelik atılımların gerçekleşmesiyle sanayi sektörü işgücü gereksinimini karşılamaya başlamıştır. Ayrıca bu yıllarda, kırsal göçün tetiklenmesi gündeme gelmiştir (Kan, 2019, s. 53).

Türkiye'nin yapısal değişikliklerine bağlı olarak, sanayi ve hizmetler sektöründeki gelişmelere paralel bir şekilde istihdamın yönü değişmektedir. 1962 yılında istihdamdaki payı \%77 olan tarımın, 2014 yılında oranı \%21,2'ye düşmüştür. Sanayinin gelişimiyle beraber sanayiye olan istihdam artmış olup, bu sektörün istihdamdaki payı 1962 yılında \%7,9 iken 2014 yılında \%20,4'e çıkmıştır. Değişim en fazla olduğu sektör hizmet sektörü olmuştur. 1962 yılında \%15,1 istihdamda paya sahip olan bu sektör, 2014 yılında \%51'e yükselmiştir. Türkiye'de tarımın öne çıktığı, ekonomik güç açısından söz sahibi olduğu bazı bölgeler bulunmaktadır. Bu bakımdan düşünüldügünde, Ege Bölgesi tarım ve sanayinin bir bütün oluşturarak ekonomik anlamda bir güç kaynağı olması bakımından güzel bir emsal teşkil etmektedir. Aydın ilinde tarım, Denizli ve Manisa'da ise tarım ve sanayi entegre bir şekilde ekonomiyi olumlu etkilemektedir. Söz konusu iller, sanayi ve tarımda oldukça önemli ve gelişmiş yöntemler uygulanarak yüksek katma değer yaratmaktadır (Bilgen ve Çılbant, 2015, s. 690).

Türkiye'de bölgelerin kendine özgü üretim potansiyellerinin olması, flora-fauna bakımından zengin bir biyolojik çeşitliliğin ve genetik kaynak tabanının oluşumunu mümkün kılmaktadır. Bu potansiyeli Türkiye'nin tarımsal değerine yansımış ve Dünya Bankası 2018 yılı verilerine göre; 2017 yılından itibaren tarımsal katma değer açısından 51.712 milyon \$ ile dünyada 8. sırada, Avrupa'da 1. sırada olmasını sağlamıştır (Kan, 2019, s. 53). Türkiye ekonomisinde tarımın gayrisafi yurt içi hasıla ve/veya istihdamdaki payı oransal olarak azalsa bile, artan nüfusun beslenmesi/barınması ve giyinmesi için tarımsal üretimin verimliliğinin artması önemlidir (Erçakar ve Taşçı, 2011, s. 183).

Tablo 2

Cari Fiyatlarla Tarımsal GSYH ve Tarımın GSYH'deki payı (2009-2019)

\begin{tabular}{rrrr}
\hline Yıllar & Tarımsal Hasıla (Bin TL) & Tarımsal Hasıla (Bin \$) & Tarımın GSYH İçindeki Payı (\%) \\
\hline $\mathbf{2 0 0 9}$ & 81.234 & 52.592 & 8,1 \\
$\mathbf{2 0 1 0}$ & 104.703 & 69.714 & 9 \\
$\mathbf{2 0 1 1}$ & 114.838 & 68.491 & 8,2 \\
$\mathbf{2 0 1 2}$ & 121.692 & 67.536 & 7,8 \\
$\mathbf{2 0 1 3}$ & 121.709 & 63.914 & 6,7 \\
$\mathbf{2 0 1 4}$ & 134.724 & 61.604 & 6,6 \\
$\mathbf{2 0 1 5}$ & 161.447 & 59.499 & 6,9 \\
$\mathbf{2 0 1 6}$ & 161.304 & 53.414 & 6,2 \\
$\mathbf{2 0 1 7}$ & 188.650 & 52.111 & 6,1 \\
$\mathbf{2 0 1 8}$ & 217.072 & 46.040 & 5,8 \\
$\mathbf{2 0 1 9}$ & 277.495 & 48.866 & 6,4 \\
\hline
\end{tabular}

Kaynak: Türkiye İstatistik Kurumu (TUIK).

Cari fiyatlardan kastedilen, enflasyonun etkisini gözetmeksizin mal ve hizmetlerin güncel değerleri üzerinden hesaplama yapılmasıdır. Tablodan görüldüğ̈̈ üzere; cari fiyatlarla tarımsal gelir, 2010 yılında 104.7 iken 2017 yılında 188.6 milyara ulaşmıştır. Ayrıca 2010 yılında tarımın toplam GSYH içerisindeki \%9 iken, 2017 yılında bu oran \%6,1 olmuştur. Son olarak da 2019 yılında tarımsal gelir 277.495 iken, tarımın toplam GSYH'deki payı \%6,4 olmuştur (Tablo 2).

\section{Tarımsal katma değer belirleyicileri}


Tarım sektörünün ekonomik aktivitelerin temelini oluşturması, bir ülkede gerek tarıma yönelik politikaların gerekse bu ülkenin ekonomi politikalarının en önemli belirleyicisi olduğunu kanıtlamaktadır (Akyol, 2018, s. 227). İnsanoğlunun yaratılışından itibaren tarım sektörü, üretim faaliyetleri-toprak mülkiyeti kapsamında birtakım evrelerden geçmiştir. Tarımsal faaliyetler, avcılık ve toplayıcılık dönemiyle başlamış, günümüzde ise bilgi-teknolojinin kullanımına dayanan uzmanlaşmış-planlı tarım işletmeciliği haline gelmiştir (Doğan, Berkman ve Arslan, 2015, s. 30-31). Teknolojik gelişmeler, tarımsal üretim kalıplarını tümüyle değiștirerek verimlilik (katma değer) kazanımlarını sağlamaktadır. Üretim teknolojilerindeki gelişmelerin sunduğu imkânları tarımsal üretim kapsamında etkin olarak kullanabilen ve küresel değer zincirine uyum sağlayabilen ülkeler için önemli firsatlar sunmaktadır. Ancak bunları takip edemeyen ülkeleri bazı sorunlarla karşı karşıya bırakmaktadır. Nitekim üretimde sürdürülebilirliğe yönelik baskıların atmasıyla günümüzde tarımsal katma değeri arttırma doğrultusundaki politika setinin tasarımında uygun politika-araç kombinasyonunun sağlanması gerekmektedir. Tarımsal katma değer artışı; kırsal istihdamda artışlar, tarımsal kesimin ekonomik altyapısında çeşitlenme, tarımsal üretime yönelik teşvikler, tarımsal nüfusun gelirinde artışlar ve finansal istikrarın sağlanması noktasında büyük önem taşımaktadır. Tarımsal katma değerin arttırılmasında iki kilit unsurdan bahsedilebilmektedir. Bunlar; (1) üretim verimliliğinin arttırılmasıyla brüt çıtıyla üretim girdileri arasındaki farkın açılması, (2) biçim, işlev, miktar veya diğer ürün ve süreç niteliklerinin değiştirilmesine bağlı olarak brüt çıktı değeriyle ara girdilerin maliyeti kapsamında marjın arttırılmasıdır (Lambert vd, 2006). Katma değerin ülke ekonomisinde meydana getirdiği etkinin boyutu ise; öncelikle üretim aşamasında, ardından girdi veren sektörlerde, son olarak sektörün piyasadaki genel durumu kapsamında belirlenmektedir. Bu doğrultuda tarımsal katma değer ve belirleyicileri detaylı bir şekilde açıklanmaya çalışılmıştır:

\section{Ekonomik Büyüme(GSYH)}

Ceylan ve Özkan (2013) tarafından, panel veri analiz yöntemi kullanılarak yapılan çalışmada 1995-2007 ve 2002-2007 yıl aralığında, 25-30 Avrupa Birliği üyesi ülke bazında tarımsal katma değerdeki artışın, kişi başına gelire katkıda bulunduğu tespit edilmiştir.

\section{Ekonomik Karmaşıklık Endeksi(EKİ)}

Soyyiğit ve Yavuzaslan (2019) tarafından yapılan çalışmada, "gelişen 7 ülke" olarak tanımlanan "E7” (Emerging 7) ülkeleri kapsamında tarımsal katma değeri etkileyen faktörlerin tespit etmek amaçlanmıştır. Panel veri analiz yönteminin kullanıldığı bu çalışmada, EKİ’nin tarımsal katma değeri etkilediği saptanmıştır. Burada ekonomik karmaşıklık artarken tarımsal katma değerin azalması şeklinde beklenen bir sonuca varılmıştır.

\section{Hükümet Etkinliği}

Hükümet etkinliği kavramsal olarak, politik kurumların ekonomik kurumlar üzerinde etkili olduğu durumu ifade etmektedir (Acemoglu ve Robinson, 2010). Soyyiğit ve Yavuzaslan (2019) tarafından yapılan panel veri analiz yönteminin kullanıldığı çalışmada hükümet etkinliğiyle tarımsal katma değer arasında iki yönlü nedensellik ilişkisinin olduğu sonucuna ulaşmıştır.

\section{Karbon $\left(\mathrm{CO}_{2}\right)$ Emisyonu}

Karbonun atmosfere salınması Karbon emisyonundan kastedilen aslında sera gazı emisyonudur. Jebli ve Yousssef (2015) tarafından En Küçük Kareler (OLS), Dinamik En Küçük Kareler (DOLS), Tam Düzeltilmiş En Küçük Kareler (FMOLS) ve Granger Nedensellik testleri kullanılarak) panel veri analiz yöntemi kapsamında yapılan çalışmada uzun vadede tarımsal katma değerin karbon emisyonunu(salınımını) azalttığı tespit edilmiştir.

\section{Politik İstikrar Endeksi}

Politik istikrar göstergesi; terörizm, politik istikrarsızlık ve politik şiddete yönelik algıyı göstermektedir. Lio ve Liu (2008) çalışmasında siyasi istikrar ve hesap verilebilirliğin tarımsal verimliliği azalttığı sonucuna ulaşmıştır. Gerekçe olarak ise; zayıf düzenlemeler ve korumacı uygulamalara sahip çoğu ülkenin tarıma yönelik yüksek dolaylı vergileri gösterilmiştir. 


\section{Tarımsal Teşvikler}

Akyol (2018) tarafından yapılan çalışmada tarımsal teşviklerdeki artışın, tarımsal katma değeri pozitif yönde (olumlu) bir etkisi olduğu sonucuna ulaşmıştır. Çalışmada 2000-2016 yıl aralığında yeni gelişen ülkeler grubuna dâhil 5 ülke (Türkiye, Güney Afrika, Meksika, Çin ve Brezilya) için panel veri analiz yöntemi kapsamındaki analizler sonucunda bu etki kanıtlanmıştır.

\section{Ampirik literatür}

Tarımın ülke ekonomisi bakımından önemi, tarımsal katma değer değişkenine ilişkin çalışmaların yapılmasını sağlamaktadır. Literatür taramasında ülke/ülke grupları ve Türkiye'de tarımsal katma değer üzerine yapılmış ulusal ve uluslararası çalışmalara yer verilmiştir. Bu konuyla ilgili ampirik çalışmalar, kronolojik sıraya göre Tablo 3'te özetlenmiştir. Kullanılan değişkenlerin çeşitliliği bakımından emsal bir çalışmanın bulunmaması nedeniyle literatüre katkı sağlayacağı düşünülmektedir.

Tablo 3

Tarımsal Katma Değerinin Belirleyicileri Üzerine Uygulamalı Literatür Özeti

\begin{tabular}{|c|c|c|c|c|}
\hline Çalışma & Metodoloji & $\begin{array}{l}\text { Zaman } \\
\text { Aralı̆gı }\end{array}$ & $\begin{array}{l}\text { Örneklem } \\
\text { Grubu }\end{array}$ & Sonuç \\
\hline $\begin{array}{l}\text { Gardner } \\
(2003)\end{array}$ & $\begin{array}{l}\text { Granger nedensellik } \\
\text { analizi }\end{array}$ & $\begin{array}{l}\text { 1961-1980, } \\
1981-2001\end{array}$ & 85 ülke & $\begin{array}{l}\text { Çalışmada; tarımsal katma değer ile } \\
\text { kişi başına milli gelir açısından güçü } \\
\text { bir nedensellik ilişkisi olduğu } \\
\text { sonucuna ulaşılmıştır. }\end{array}$ \\
\hline $\begin{array}{l}\text { Lio ve Liu } \\
(2008)\end{array}$ & Panel veri yöntemi & $\begin{array}{l}\text { 1996-1998, } \\
2000-2002\end{array}$ & 127 ülke & $\begin{array}{l}\text { Çalışmada ulaşılan bulgulara göre; } \\
\text { hukukun üstünlüğü endeksi tarımsal } \\
\text { verimliliği arttırırken, politik istikrar } \\
\text { endeksi tarımsal verimliliği } \\
\text { azaltmaktadır. }\end{array}$ \\
\hline $\begin{array}{l}\text { Erçakar ve } \\
\text { Taşçı (2011) }\end{array}$ & Panel veri yöntemi & $1972-2008$ & Türkiye & $\begin{array}{l}\text { Çalışmada ulaşılan bulgulara göre; } \\
\text { verimlilikteki artış çiftçinin elde ettiği } \\
\text { nominal fiyatları arttırırken, reel } \\
\text { fiyatları azaltmaktadır. }\end{array}$ \\
\hline $\begin{array}{l}\text { Ceylan ve } \\
\text { Özkan (2013) }\end{array}$ & $\begin{array}{l}\text { Panel veri analiz } \\
\text { yöntemi }\end{array}$ & $\begin{array}{l}\text { 1995-2007, } \\
\text { 2002-2007 }\end{array}$ & $\begin{array}{l}\text { 25-30 } \\
\text { Avrupa } \\
\text { Birliği üyesi } \\
\text { ülke }\end{array}$ & $\begin{array}{l}\text { Çalışmada ulaşılan bulgulara göre; } \\
\text { tarımsal katma değerdeki artışın, kişi } \\
\text { başına gelire katkıda bulunduğu } \\
\text { belirtilmiştir }\end{array}$ \\
\hline $\begin{array}{l}\text { Rizov, } \\
\text { Pokrivcak ve } \\
\text { Ciaian }(2013)\end{array}$ & regresyon & $1990-2008$ & $\begin{array}{l}15 \text { Avrupa } \\
\text { Birliği üyesi } \\
\text { ülke }\end{array}$ & $\begin{array}{l}\text { Çalışmada, üretimden bağımsız } \\
\text { doğrudan destekleyici yardımlar } \\
\text { reformundan önceki teşvikler katma } \\
\text { değeri olumsuz, reform } \\
\text { sonrasındakiler ise tarımsal katma } \\
\text { değeri olumlu yönde etkilediği tespit } \\
\text { edilmiştir. }\end{array}$ \\
\hline
\end{tabular}

Tablo 3

Tarımsal Katma Değerinin Belirleyicileri Üzerine Uygulamalı Literatür Özeti (Devamı) 


\begin{tabular}{|c|c|c|c|c|}
\hline Çalışma & Metodoloji & $\begin{array}{l}\text { Zaman } \\
\text { Aralığı }\end{array}$ & $\begin{array}{l}\text { Örneklem } \\
\text { Grubu }\end{array}$ & Sonuç \\
\hline $\begin{array}{l}\text { Jebli } \quad \text { ve } \\
\text { Yousssef } \\
(2015)\end{array}$ & $\begin{array}{l}\text { Panel } \\
\text { eşbütünleşme }\end{array}$ & $1980-2011$ & $\begin{array}{l}\text { Cezayir, } \\
\text { Misir, Fas, } \\
\text { Sudan ve } \\
\text { Tunus }\end{array}$ & $\begin{array}{l}\text { Çalışmada ulaşılan bulgulara göre; } \\
\text { uzun dönemde tarımsal katma } \\
\text { değerin karbon emisyonunu } \\
\text { (salınımını) azalttığı, GSYH artışının } \\
\text { da üretimde fosil yakıt kullanımına } \\
\text { başvurmasından ötürü karbon } \\
\text { emisyonunu azalttığı tespit edilmiştir. }\end{array}$ \\
\hline $\begin{array}{l}\text { Asom ve } \\
\text { Ijirshar (2016) }\end{array}$ & $\begin{array}{l}\text { Genişletilmiş Dickey- } \\
\text { Fuller Birim Kök Testi } \\
\text { (Augmented Dickey- } \\
\text { Fuller Test; ADF), } \\
\text { Johansen } \\
\text { eşbütünleşme testi ve } \\
\text { Hata düzeltme modeli }\end{array}$ & 1981-2015 & Nijerya & $\begin{array}{l}\text { Çalışmada; hem kısa hem de uzun } \\
\text { dönem için tarımsal katma değerin } \\
\text { ekonomik büyüme üzerinde pozitif } \\
\text { bir etkisi olmasına rağmen bu etkinin } \\
\text { istatistiksel olarak anlamlı olmadığ } 1 \\
\text { belirtilmiştir. }\end{array}$ \\
\hline Akyol (2018) & $\begin{array}{l}\text { Panel veri analiz } \\
\text { yöntemi }\end{array}$ & 2000-2016 & $\begin{array}{l}\text { Güney } \\
\text { Afrika, } \\
\text { Türkiye, } \\
\text { Çin, } \\
\text { Brezilya ve } \\
\text { Meksika }\end{array}$ & $\begin{array}{l}\text { Çalışmada tarımsal teşviklerin, } \\
\text { tarımsal katma değeri üzerinde pozitif } \\
\text { yönde (olumlu) bir etkisi olduğu } \\
\text { sonucuna ulaşılmıştır. }\end{array}$ \\
\hline $\begin{array}{l}\text { Yavuzaslan ve } \\
\text { Soyyiğit } \\
(2019)\end{array}$ & $\begin{array}{l}\text { Panel veri analiz } \\
\text { yöntemi }\end{array}$ & 1996-2017 & $\begin{array}{l}\text { Türkiye, } \\
\text { Brezilya, } \\
\text { Rusya, } \\
\text { Hindistan, } \\
\text { Çin, } \\
\text { Meksika ve } \\
\text { Endonezya } \\
\text { (E-7) }\end{array}$ & $\begin{array}{l}\text { Çalışmada, hükümet etkinliği ile } \\
\text { tarımsal katma değer bazında çift } \\
\text { yönlü nedensellik saptanmıştır. }\end{array}$ \\
\hline $\begin{array}{l}\text { Çuhadar } \\
\text { (2020) }\end{array}$ & $\begin{array}{l}\text { Sistem } \\
\text { Genelleştirilmiş } \\
\text { Momentler } \\
\text { Yöntemi } \\
\text { (Sistem GMM) }\end{array}$ & -2014 & 20 ülke & $\begin{array}{l}\text { Çalışmada; tarımsal katma değer, } \\
\text { katılımcı demokrasi ve enerji } \\
\text { kullanımının karbon emisyonu } \\
\text { üzerinde istatistiksel olarak anlamlı } \\
\text { bir etkisi olduğu belirtilmiştir. }\end{array}$ \\
\hline
\end{tabular}

Kaynak: Literatür taraması neticesinde yazarlar tarafından tablolaştırılmıştır.

\section{Araştırma Yöntemi}

Bu çalışmada, 2000-2018 dönemi bazında 20 ülke için tarımsal katma değer belirleyicilerini tespit etmek amacıyla panel veri analiz yöntemi kullanılmıştır. Çalışmada, farklı gelişmişlik seviyelerinde olup tarımsal katma değer açısından dikkat çeken ülkeler tercih edilmiştir. Analizde; sabit etkiler modeli, rassal (tesadüfi) etkiler modeli, genelleştirilmiş momentler yöntemi (GMM), sistem GMM ve robust (dirençli hata) tahmincileri ekonometrik modelleri kullanılmıştır. Tarımsal ürün katma değeri (bağımlı değişken) belirleyicileri olarak ise; kişi başına gayrisafi yurtiçi hasıla (GSYH), brüt sabit sermaye oluşumu, tarımsal işgücü oranı (toplam işgücü\%), kentleşme oranı (toplam nüfus\%), politik istikrar ve hukukun üstünlüğü endeksi serileri (bağımsız değişkenler) ele alınmıştır. Çalışmada kullanılan veriler, Dünya Bankası ve Dünya Genelinde Yönetişim Göstergeleri sitelerinden temin edilmiştir. Bu çalışma etik kurul izin belgesi gerektirmemektedir.

\section{Veri Seti ve Metodoloji}

Panel verinin ayırıcı özelliği, bir zaman serisi/kesit analizini içermeden tek başına daha gerçekçi modellerin analizini mümkün kılmasıdır. Panel verileri (kesitsel-boylamsal serileri) varlıkların tutumlarının zaman içinde gözlemlendiği bir veri kümesi olup $\mathrm{N}$ sayıda birim, birimlerin her biri için $\mathrm{T}$ tane gözlem yer almaktadır (Torres ve Reyna, 2007). Panel veri modeli aşağıda formülize edilmiştir: 


$$
\mathrm{Y}_{\text {it }}=\mathrm{X}_{\text {it }} \beta+\mu_{\mathrm{i}}+\mathrm{u}_{\mathrm{it}} \quad \mathrm{i}=1, \ldots, \mathrm{N} \quad \mathrm{t}=1, \ldots, \mathrm{T} \quad \text { (1) }
$$

Eşitlikte zaman "t", birim ise " $N$ ” ile gösterilmiştir. Y değişkeni ardışık zamana ve farklı kesitlere bağlı olarak değerleri değişebildiğinden dolayı i ve t olarak iki alt indisi içermektedir. Hata terimi bileşenleri ise aşağıda formülize edilmiştir:

$$
\mathrm{u}_{\mathrm{it}}=\mu_{\mathrm{i}}+v_{\mathrm{it}}
$$

Burada; $\nu_{\text {it }}$ geri kalan (remainder) etkileri, $\mu_{\mathrm{i}}$ ise kesitin belli bileşenlerini temsil etmektedir (Baltagi, Feng ve Kao, 2011, s. 306).

Panel regresyonlarında, rassal etkiler (RE) modeli-sabit etkiler (FE) modeli olmak üzere iki temel yaklaşım kullanılmaktadır. Sabit etkiler (FE) modeli, zamana bağlı olarak verilerde gözlenen değişimi ortaya koymaktadır. Bu model, araştırmada tartışılan bağımlı-bağımsız değişkenler arasındaki ilişkiyi incelemektedir. Beli niteliklerdeki birimler (ülke, kişi ve şirket vb.) tahmin edilen değişkenleri etkileyebilmekte veya etkileyememektedir. Bontempi ve Golinelli çalışmalarında (aktaran Bal ve Özdemir, 2017) sabit etkiler modeli aşağıdaki gibi formüle edilmiştir:

$$
\begin{array}{r}
\mathrm{Y}_{\mathrm{it}}=\alpha+\beta \mathrm{X}_{\mathrm{it}}+\sum \mu_{j} D_{i j} N-1 \\
j=1+\varepsilon_{\mathrm{it}} \mathrm{N} \text { yapisal sabit } \\
\mathrm{Y}_{\mathrm{it}}=\alpha+\beta \mathrm{x}_{\mathrm{it}}+\sum \mu_{j} D_{i j} N-1 \\
j=1+\sum \mathrm{T}_{j} D_{i j} N-1 \\
j=1+\varepsilon_{\mathrm{it}} \mathrm{N} \text { ve T yapisal sabit }
\end{array}
$$

Rassal etkiler (RE) modelinde, sabit etkiler modelinden farklı sonuçlar gözlemlenebilmektedir. Bu farklılıklardan en önemlisi, bağımlı ve bağımsız değişkenlerin birbiriyle alakasız olmasıdır. Bontempi ve Golinelli çalışmalarında (aktaran Bal ve Özdemir, 2017) rassal etkiler modeli aşağıdaki gibi formüle edilmiştir:

$$
\begin{aligned}
& Y_{i t}=\alpha+\beta X_{i t}+v_{2 i t} V_{2 i t}=\varepsilon_{i t}+\mu_{i} \text { tek yönlü model } \\
& Y_{i t}=\alpha+\beta X_{i t}+v_{3 i t} V_{3 i t}=\varepsilon_{i t}+\mu_{i}+T_{t} \text { çift yönlü model }
\end{aligned}
$$

Analizlerde kullanılan tahmin yöntemi dayanıklı-dirençli (robust) ve dayanıklı olmayan yöntem olarak adlandırılabilmektedir. Robust (dirençli-dayanıklı) tahminciler, veri kümesinde güvenli gözlemlerin homojen dağılmadığında güvenli sonuçlar bularak sapan değerlerin etkisini azaltma amacıyla kullanılmaktadır. Bir başka yaklaşıma göre, bir tahminci veride bulunan aykırı gözlem(ler)den etkilendiğinde o tahminci dayanıklı (robust), etkilenmediğinde ise dayanıklı olmayan tahminci olarak ifade edilmektedir. Gerek tahmincilerin dayanıklılık özelliği gerekse bu dayanıklılığın derecesi öncelikle "kırılma noktası (breakdown point), etki fonksiyonu (influence function) ve hassasiyet eğrisi (sensivitiy curve)" olmak üzere çeşitli büyüklüklerle açıklanmaktadır. Tahmincinin kırılma noktası 0'dan büyükse o tahmincinin dirençli-dayanıklı (robust) olduğunu belirtmek mümkündür.

Model seçimi aşamasında panel veri analizleri kapsamında sıklıkla tercih edilen Hausman (1978) testi temel olarak birim veya zaman etkilerini ve bağımsız değişkenler arasındaki korelasyonunu tespit etmeyi hedeflemektedir. Birim ve zaman etkileri bağımsız değişkenlerle korelasyonsuz olduğunda tesadüfi etkiler modeli daha tutarlı olmakta ve bu durumda tesadüfi etkiler modelinin tercih edilmesi daha uygun olmaktadır. Birim ve zaman etkileri bağımsız değişkenlerle korelasyonlu olduğunda ise tesadüfi etkiler tahmincisi sabit etkiler tahmincisine kıyasen daha sapmalı sonuçlar vermekte ve sabit etkiler tahmincisinin tutarlı olmasından dolayı sabit etkiler modelinin tercih edilmesi uygun olmaktadır. Hausman test istatistiği Ki-kare dağılımını göstermektedir. Bu test istatistiğinin matris formundaki hesaplanması aşağıdadır; 


$$
\mathrm{H}=\left(\widehat{\beta}_{\mathrm{FE}}-\widehat{\beta}_{\mathrm{RE}}\right)^{\prime}\left[\operatorname{Avar}\left(\widehat{\beta}_{\mathrm{FE}}\right)-\operatorname{Avar}\left(\widehat{\beta}_{\mathrm{RE}}\right)\right]^{-1}\left(\widehat{\beta}_{\mathrm{FE}}-\widehat{\beta}_{\mathrm{RE}}\right)
$$

$\mathrm{Bu}$ denklemde; FE sabit etkiler modelinin tahmincilerini, RE ise tesadüfi etkiler modelinin tahmincilerini temsil etmektedir. Avar $\left(\hat{\beta}_{\mathrm{FE}}\right)$ ve $\operatorname{Avar}\left(\hat{\beta}_{\mathrm{RE}}\right)$ tahminlerde ulaşılan asimptotik varyans kovaryans matrisleri anlamına gelmektedir. Hesaplanan bu test istatistiğinin sıfıra eşitliği sınanmaktadır. Testin hipotezlerine aşağıda yer verilmiştir:

$$
\begin{aligned}
& \mathrm{H}_{0}=\text { Bağımsız değişkenlerle birim ve zaman etki arasında korelasyon yoktur. } \\
& \mathrm{H}_{\mathrm{a}}=\text { Bağımsız değişkenlerle birim ve zaman etki arasında korelasyon vardır. }
\end{aligned}
$$

Dolayısıyla hipotez reddedilemediğinde tesadüfi (rassal) etkiler modeli, hipotez reddedildiğinde sabit etkiler modeli tercih edilebilmektedir.

Dinamik panel veri analizlerinde sıklıkla tercih edilen model, Arellano ve Bond (1991)'un önerdiği “Genelleştirilmiş Momentler Yöntemi” (GMM)'dir. Arellano ve Bond (1991), Anderson ve Hsiao (1981) yöntemini geliştirerek dinamik panel veri modellerinde bütün geçerli gecikmeli değişkenlerin araç değişken biçiminde kullanımını önermiş ve genelleştirilmiş momentler yöntemini (GMM, Generalized Method of Moments) geliştirmiştir. Hata terimleri otokorelasyonlu olduğunda kullanılan bu yöntem, gerek sabit varyans gerekse değişen varyans olması durumunda uygun bir yöntem olmaktadır. Genelleştirilmiş momentler metodu tahminciler, örneklem ve kitle momentlerinin eşitlenmesi ilkesine dayanan momentler metodunu temel almaktadır. GMM için kullanılan temel tahminci modelleri: “Araç Değişken (IV-Instumental Variable) Tahmincisi, Arellano-Bond Tahmincisi ve Arellano-Bover Tahmincisi”dir. Ayrica sonradan, Arellano ve Bover (1995) tarafından, Sistem-GMM tahmincisi geliştirilmiştir (Akay, 2015, s. 95).

Çalışmada kullanılan tarımsal katma değeri belirleyici faktörlere ilişkin değişkenler, logaritmaları alınarak aşağıdaki gibi formülize edilmiştir:

$\log (A V A)_{i t}=\alpha_{0 i}+\beta_{1} \log (G D P)_{i t}+\beta_{2}(G C F)_{i t}+\beta_{3}(E A)_{i t}+\beta_{4}(U P)_{i t}+\beta_{5}(P S)_{i t}+\beta_{5}(R L)_{i t}+\varepsilon_{i t}$

Burada; $\mathrm{i}=1, \ldots, \mathrm{N}$ ülkeleri; $\mathrm{t}=, 1 \ldots, \mathrm{T}$ zaman boyutunu ve $\varepsilon$ hata terimini temsil etmektedir.

\begin{tabular}{|c|c|c|}
\hline Değişken & Açılama & Veri Kaynağı \\
\hline AVA & Cari İşlemler Açı̆̆ & Dünya Bankası-World Bank (WB) \\
\hline GDP & Kişi başına GSYH & Dünya Bankası-World Bank (WB) \\
\hline GCF & Brüt Sabit Sermaye & Dünya Bankası-World Bank (WB) \\
\hline EA & $\begin{array}{l}\text { Tarımsal işgücü oranı } \\
\text { (toplam işgücü\%) }\end{array}$ & Dünya Bankası-World Bank (WB) \\
\hline UP & $\begin{array}{l}\text { Kentleşme oranı(toplam } \\
\text { nüfus\%) }\end{array}$ & Dünya Bankası-World Bank (WB) \\
\hline PS & $\begin{array}{l}\text { Politik İstikrar ve } \\
\text { Şiddetin/Terörizmin } \\
\text { Yokluğu }\end{array}$ & $\begin{array}{l}\text { Dünya Genelinde Yönetişim Göstergeleri- } \\
\text { Worldwide Governance Indicators (WGI) }\end{array}$ \\
\hline RL & $\begin{array}{l}\text { Hukukun Üstünlüğü } \\
\text { Endeksi }\end{array}$ & $\begin{array}{l}\text { Dünya Genelinde Yönetişim Göstergeleri- } \\
\text { Worldwide Governance Indicators (WGI) }\end{array}$ \\
\hline
\end{tabular}

Tablo 4

Analizde Kullanılan Değişkenlerle İlgili Açıklamalar

Kaynak: Yazarlar tarafından analizde kullanılan değişkenlerle ilgili açıllamalar verilmiştir.

Tablo 4’te, analizde yer verilen değişkenler kapsamındaki açıklamalar/değişkenler/veri kaynağı görülmektedir. 


\section{Araştırma Bulguları}

$\mathrm{Bu}$ çalışmada tarımsal katma değeri belirleyen faktörlerin tahmininde sabit etkiler, rassal (tesadüfi) etkiler, Arrellano\&Bond (1991) tarafından geliştirilen dinamik GMM (Genelleştirilmiş Momentler Metodu), sistem GMM ve robust (dirençli hata) tahmincileri modellerine birlikte yer verilmiştir. Çalışmada, panel veri analiz yöntemlerine yönelik olarak ele alınan bu modeller bağımlı ve bağımsız değişkenler arasındaki ilişkinin istatistiksel olarak anlamlılı̆̆ı ve yönünü tespit etmek amacıyla kullanılmıştır.

Sabit etkiler tahmincisi her zaman sabit (consistent) olduğundan dolayı ağırlıklı olarak tesadüfi (rassal) etkiler modeli üzerinde durulmaktadır. Varsayımın geçersizliği durumunda tesadüfi (rassal) etkiler tutarsız (inconsistent) olmaktadır. Dolayısıyla özellikle tesadüfi (rassal) etkiler modelini kullanabilmek için Hausman testiyle onay verilmesi gerekmektedir. Öncelikle literatür kapsamında model seçiminde sıkça kullanılan Hausman test sonuçları, Tablo 5'de gösterilmiştir.

Tablo 5

Hausman Testi Sonuçları

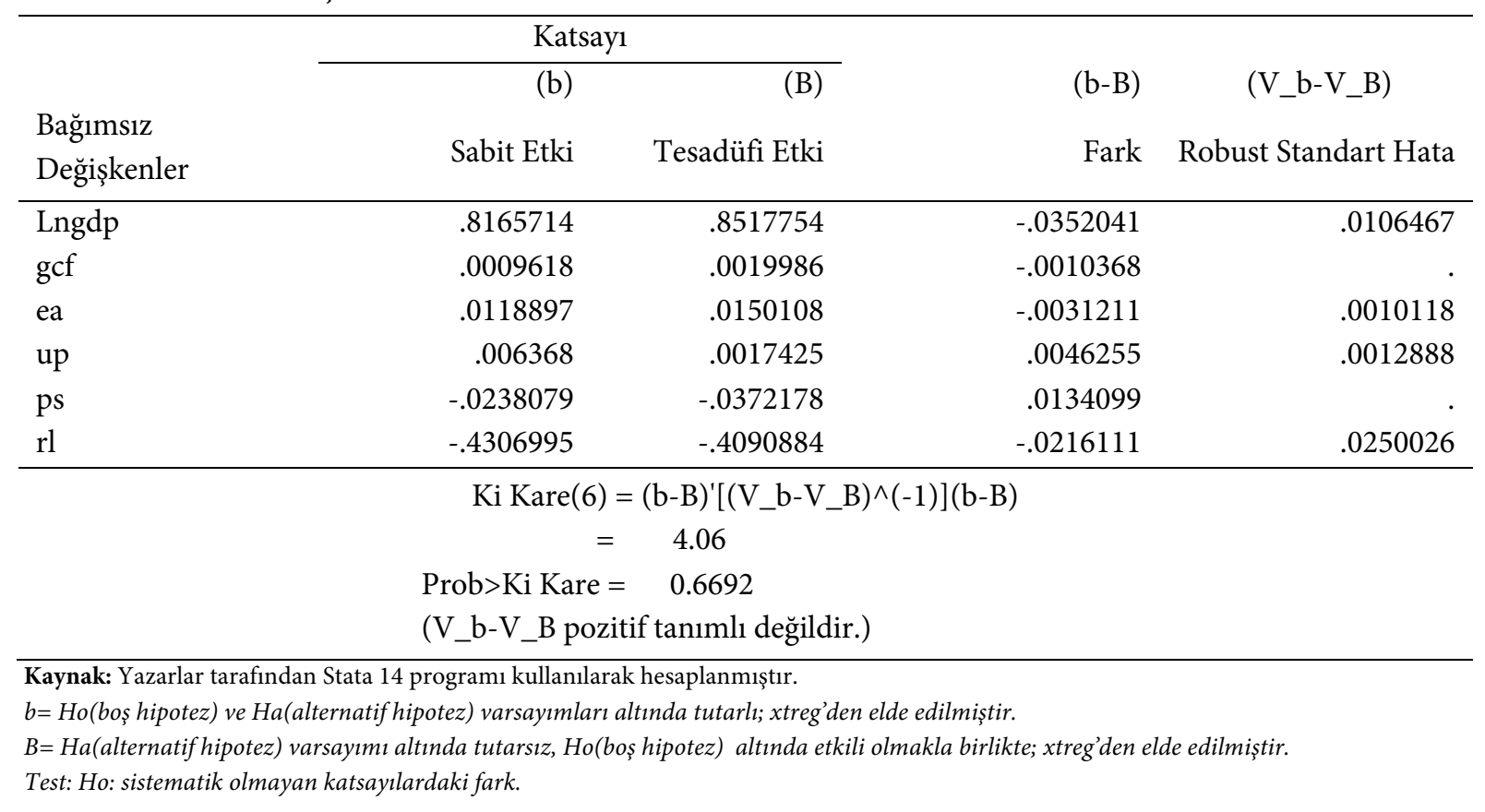

Hausman test sonuçları incelendiğinde olasılık değeri Prob $>$ Ki kare=0,6692 olduğu görülmektedir. Bu tabloya göre; boş hipotezi reddedecek kadar anlamlı bir sonuç vermemiştir. Dolayısıyla bu modelde, tesadüfi (rassal) etkiler modeli tercih edilmelidir (Tablo 5). Ancak analizin daha net anlaşılması adına; sabit etkiler, tesadüfi etkiler ve GMM (genelleştirilmiş momentler yöntemi) ve sistem GMM modelleri karşılaştırmalı olarak gösterilecektir. Tahminlerle ilgili sonuçlar Tablo 6’ da raporlanmıştır.

Tablo 6 
Tarımsal Katma Değer Belirleyicileri: 2000-2018, tesadüfi etkiler, sabit etkiler ve GMM tahmin sonuçları (bağımlı değişken tarımsal katma değer logaritması)

\begin{tabular}{|c|c|c|c|c|c|c|c|}
\hline Değişkenler & $\begin{array}{l}\text { GMM_- } \\
\text { Robust }\end{array}$ & Sabit & Sabit_Robust & Rassal & $\begin{array}{l}\text { Rassal_ } \\
\text { Robust }\end{array}$ & GMM & $\begin{array}{l}\text { Sistem } \\
\text { GMM }\end{array}$ \\
\hline \multirow[t]{2}{*}{ L.Inava } & $0.242^{\star * *}$ & & & & & $0.242^{\star * *}$ & $0.839^{\star * *}$ \\
\hline & $(0.0432)$ & & & & & $(5.60)$ & $(39.44)$ \\
\hline \multirow[t]{2}{*}{ Lngdp } & $0.658^{\star * *}$ & $0.817^{\star * *}$ & $0.817^{\star * *}$ & $0.852^{* * *}$ & $0.852^{\star * *}$ & $0.658^{\star * *}$ & $0.121^{\star * *}$ \\
\hline & $(0.049)$ & $(0.0264)$ & $(0.0644)$ & $(0.0242)$ & $(0.0551)$ & $(13.43)$ & $(6.57)$ \\
\hline \multirow[t]{2}{*}{ gcf } & -0.00137 & 0.000962 & 0.000962 & 0.002 & 0.002 & -0.00137 & $0.00678^{\star * *}$ \\
\hline & $(0.0019)$ & $(0.00242)$ & $(0.00482)$ & $(0.00248)$ & $(0.00533)$ & $(-0.72)$ & (3.73) \\
\hline \multirow[t]{2}{*}{ ea } & $0.0251^{\star * *}$ & $0.0119^{\star * *}$ & 0.0119 & $0.0150^{* * *}$ & $0.0150^{\star}$ & $0.0251^{\star * *}$ & $0.00797^{\star * *}$ \\
\hline & $(0.00795)$ & $(0.00347)$ & $(0.0105)$ & $(0.00331)$ & $(0.00814)$ & $(3.16)$ & $(5.01)$ \\
\hline \multirow[t]{2}{*}{ up } & 0.0107 & $0.00637^{\star}$ & 0.00637 & 0.00174 & 0.00174 & 0.0107 & $0.00303^{* *}$ \\
\hline & $(0.00879)$ & $(0.00367)$ & $(0.00793)$ & $(0.00343)$ & $(0.00723)$ & $(1.22)$ & $(2.68)$ \\
\hline \multirow[t]{2}{*}{ ps } & -0.0667 & -0.0238 & -0.0238 & -0.0372 & -0.0372 & -0.0667 & -0.0346 \\
\hline & $(0.0453)$ & $(0.025)$ & $(0.0852)$ & $(0.0255)$ & $(0.0857)$ & $(-1.47)$ & $(-1.76)$ \\
\hline \multirow[t]{2}{*}{$\mathrm{rl}$} & $-0.282^{\star * *}$ & $-0.431^{\star * *}$ & $-0.431^{\star * *}$ & $-0.409^{* * *}$ & $-0.409^{* * *}$ & $-0.282^{\star * *}$ & $-0.0406^{\star}$ \\
\hline & $(0.0765)$ & $(0.0596)$ & $(0.121)$ & $(0.0541)$ & $(0.0972)$ & $(-3.69)$ & $(-2.54)$ \\
\hline \multirow[t]{2}{*}{ Sabit } & -0.701 & $1.313^{\star}$ & 1.313 & 0.574 & 0.574 & -0.0701 & 0.138 \\
\hline & $(1.654)$ & $(0.712)$ & $(1.951)$ & $(0.672)$ & $(1.549)$ & $(-0.42)$ & $(0.64)$ \\
\hline Gözlemler & 318 & 358 & 358 & 358 & 358 & 318 & 338 \\
\hline R-kare & & 0.88 & 0.88 & & & & \\
\hline Ülke sayısı & 20 & 20 & 20 & 20 & 20 & & \\
\hline \multicolumn{8}{|c|}{ Robust standart hatalar parantez içindedir. } \\
\hline
\end{tabular}

Kaynak: Yazarlar tarafından Stata 14 programı kullanılarak hesaplanmıştır.

Tahmin neticesinde elde edilen bulgulara göre; bağımlı değişken olan tarımsal katma değer ile bağımsız değişken olan kişi başına GSYH arasında pozitif yönlü ve anlamlı bir ilişki olduğu tespit edilmiştir (Tablo 6 . Sabit Etki, Rassal Etki, GMM ve Sistem GMM). Tarımsal katma değer ile brüt sabit sermaye oluşumu arasında ise istatistiksel olarak anlamlı ve pozitif yönlü bir ilişki saptanmıştır (Tablo 6. Sistem GMM). Tarımsal katma değer ile tarımsal işgücü oranı (toplam işgücü\%) arasında da pozitif yönlü ve anlamlı bir ilişki olduğu saptanmıştır (Tablo 6. Sabit Etki, Rassal Etki, GMM ve Sistem GMM). Tarımsal katma değer ile kentleşme oranı (toplam nüfus\%) arasında istatistiksel olarak anlamlı ve pozitif bir ilişki bulunmuştur (Tablo 6. Sabit Etki ve Sistem GMM). Ancak tarımsal katma değer ile politik istikrar göstergesi arasında herhangi bir ilişki tespit edilememiştir (Tablo 6. Sabit Etki, Rassal Etki, GMM ve Sistem GMM). Ayrıca tarımsal katma değer ile hukukun üstünlügü endeksi arasında anlamlı ancak negatif yönlü bir ilişki tespit edilmiştir (Tablo 6. Sabit Etki, Rassal Etki, GMM ve Sistem GMM). Bu çalışmada, modelin beklentilerle uyumlu bir şekilde istatistiksel bakımdan anlamlılı̆̆ı kanıtlanmıştır. Yapılan analizde elde edilen bulgulara göre; seçilen ülkeler kapsamında değerlendirilen modelde, bağımlı değişken olan tarımsal katma değer, diğer tüm bağımsız değişkenler tarafından \% 88 açıklanmaktadır. 


\section{Sonuç ve Tartışma}

Stratejik açıdan tarım, elzem bir sektör olmasına rağmen tarımsal üretim, doğa koşullarına tabi olmakta, bu koşullar özellikle bitkisel üretim açısından öne çıkmaktadır. Doğa koşullarına müdahale etme olanağının düşük olması nedeniyle üretim koşulları kapsamında müdahale edilebilir alanlara yönelerek tarımsal verimliliği artırmak gerekmektedir. Keza tarımsal ürünler için kullanılan üretim faktörlerinin (emek, tohum, gübre, makine teçhizat ve teknoloji gibi girdilerin) ulusal kaynaklardan karşılanma düzeyi, verimliliğin (katma değerin) boyutunun belirlenmesi açısından büyük önem taşımaktadır. Ayrıca tarımsal üretim değeri bazında dünyada hatırı sayılır ülkeler arasında olan Türkiye'de üretim değerinin oluşumunda doğal koşullar, beşeri ve fiziki sermaye yapısı dikkat çekmektedir.

Çalışmada, seçilen 20 ülke bazında tarımsal katma değerde belirleyici faktörler tespit edilmeye çalışılmıştır. Bu doğrultuda tarımsal katma değerin belirleyicileri olarak kişi başına gayrisafi yurtiçi hasıla (GSYH), brüt sabit sermaye oluşumu, tarımsal işgücü oranı (toplam işgücü\%), kentleşme oranı (toplam nüfus\%), politik istikrar ve hukukun üstünlüğü endeksi serileri alınmıştır. Çalışmada, 2000-2018 yılları arası yıllık verileri bazında panel veri analiz yöntemi kullanılarak sabit ekiler, tesadüfi (rassal) etkiler, GMM, sistem GMM ve robust (dirençli hata) tahmincileri ekonometrik modelleri ile incelenmiştir. Bu inceleme kapsamında elde edilen bulgulara göre; bağımlı değişken olan tarımsal katma değer ile arasında anlamlı ve pozitif yönlü bir ilişki saptanan bağımsız değişkenler; kişi başına GSYH, brüt sabit sermaye oluşumu, tarımsal işgücü oranı (toplam işgücü\%) ve kentleşme oranı (toplam nüfus\%) olmuştur. Tarımsal katma değer ile arasında anlamlı fakat negatif yönde bir ilişki tespit edilen bağımsız değişken ise; hukukun üstünlüğü endeksi olmuştur. Bu durum, ekonomik açıdan refah artışı gösteren ülkelerde tarımın GSYH'deki payının düşmesiyle ilişkili olarak yorumlanabilmektedir. Dolayısıyla hukukun üstünlüğü endeksi ile tarımsal katma değer arasındaki ters yönlü ilişkiyi bu şekilde açılklamak mümkündür. Buna bir örnek vermek gerekirse; tarımla karşılaştırıldığında verimlilik (katma değer), imalat ve hizmetler sektöründe daha yüksek olma eğilimindedir ki işgücünün daha verimli alanlara kaydırılması iktisadi büyümenin önemli bir kaynağını teşkil etmektedir. Son olarak tarımsal katma değer ile bağımsız değişkenlerden politik istikrar endeksi arasında istatistiksel olarak anlamlı bir ilişki saptanamamıştır. Bu çalışmada, modelin beklentilerle uyumlu olarak istatistiksel bakımdan anlamlı olduğu görülmektedir. Bu çalışmanın farklı ve orijinal yönü (özgün değeri), tarımsal katma değerin etkilenebileceği değişkenlerin ekonomik, sosyal, siyasi ve hukuki çerçevede kategorilere ayrılarak saptanmasıdır. Literatürdeki diğer çalışmalarda genellikle değişkenler kategorileştirmeksizin tek bir niteliğe göre (örneğin sadece ekonomik yönü üzerinde) inceleme yapılmıştır.

Ülkeler bazında tarımsal katma değerin kişi başına GSYH ile birlikte artan bir eğilimde olması ve bunun uzun vadede sürdürülmesi; tarımda mekanizasyon ve yüksek teknoloji kullanımına yönelik üretim verimliliğinin arttırılmasına ve ürün kalitesinin iyileştirilmesine bağlı olmaktadır. Bir başka deyişle, ülkelerde tarımsal katma değeri (verimliliği) artırabilecek teknolojiye ve dijitalleşmeye yönelik yatırımlar desteklenmelidir. Üreticiye yönelik toplam katma değerden alınan payı arttırma doğrultusunda yalnızca teşvik değil, bunun yanı sıra örgütlenme politikaları da geliştirilmelidir. Son olarak da şunu belirtmek gerekir ki, nitelikli işgücünün tarımsal üretime yönlendirilmesiyle girişimcilik ve agro-turizm desteklenmelidir. 


\section{Kaynakça}

Acemoglu, D. ve Robinson, J. A. (2010). The role of institutions in growth and development. Review of Economics and Institutions, 1(2), 1-33. doi:10.5202/rei.v1i2.1.

Akay, Ç. E. (2015). Dinamik panel veri modelleri, stata ile panel veri modelleri. İstanbul: Der Yayınları.

Akyol, M. (2018). Tarımsal teşviklerle tarımsal katma değer arasındaki ilişkinin incelenmesi: Yeni endüstrileşen ülkeler için panel eşanlı denklemler sistemi analizi. The Journal of International Scientific Researches, 3(3), 226-236. doi:10.23834/isrjournal.456791.

Asom, S. T. ve Ijirshar, V. U. (2016). Impact of agriculture value added on the growth of Nigerian economy. Nigerian Journal of Management Sciences, 5(1), 239-245. Erişim adresi:https://www.researchgate.net/publication/331843284_Impact_of_Agriculture_Value_Added_ on_the_Growth_of_Nigerian_Economy.

Bal, H. ve Özdemir, P. (2017). Kurumlar ve ekonomik gelişme: Panel veri analizi ile bir değerlendirme. Gazi Üniversitesi Sosyal Bilimler Dergisi, 4(9), 80-104. Erişim adresi: https://dergipark.org.tr/tr/pub/gusbd/issue/29519/316843.

Baltagi, B., Feng, Q. ve Kao, C. (2011). Testing for sphericity in a fixed effects panel data model. Econometrics Journal, 14, 25-47. doi: 10.1111/j.1368-423X.2010.00331.x.

Bilgen, U. ve Çılbant, C. (2015). Manisa Gördes'de 2008-2014 yılları arasında tarımsal üretim-fiyat ilişkisi. Yönetim ve Ekonomi Celal Bayar Üniversitesi İktisadi ve İdari Bilimler Fakültesi Dergisi, 22(2), 685697. doi: $10.18657 /$ yecbu.06527.

Ceylan, F. ve Ozkan B. (2013). Agricultural value added and economic growth in European Union accession process. Mediterranean Journal of Economics, Agriculture and Environment, 12(4), 62-71. Erişim adresi: https://newmedit.iamb.it/2013/10/10/agricultural-value-added-and-economic-growthin-theeuropean-union-accession-process.

Çetin, B. (2010). Tarım ekonomisi. Bursa: Dora Yayınları.

Çuhadar, P. (2020). Gelişmekte olan ülkelerde politik ekonomi, iklim değişikliği ve tarım ilişkisinin dinamik panel veri analizi. Tarm Ekonomisi Dergisi, 26(1), 41-50. doi:10.24181/tarekoder.697179.

Doğan, Z. ve Berkman, A. N. ve Arslan, S. (2015). Türkiye'de tarım sektörünün iktisadi gelişimi ve sorunları. Niğde Üniversitesi İktisadi ve İdari Bilimler Fakültesi Dergisi, 8(1), 29-41. Erişim adresi: https://dergipark.org.tr/tr/pub/niguiibfd/issue.

Dünya Ticaret Örgütü. (2019). Merchandise world exports by major product groups. Erişim adresi: https://www.wto.org/english/res_e/statis_e/wts2019_e/wts2019_e.pdf.

Erçakar, M. E. ve Taşçı, M. H. (2011). Tarım ürünlerinde verimlilik-fiyat ilişkisi: Türkiye üzerine ampirik bir uygulama. Elektronik Sosyal Bilimler Dergisi (elektronik), 10(36), 171-186. Erişim adresi: https://app.trdizin.gov.tr/publication/paper/detail.

Erkuş, A., Bülbül, M., Kıral, T., Açıl, F. ve Demirci, R. (2005). Tarım ekonomisi. Ankara: Ankara Üniversitesi Ziraat Fakültesi Eğitim, Araştırma ve Geliştirme Vakfı Yayınları.

Garcia, G. J. (1981). The effects of exchange rates and commercial policy on agricultural incentives in Colombia: 1953-1978. (Rapor No. 24). Colombia: International Food Policy Research Institute.

Gardner, B. L. (2005). Causes of rural economic development. Agricultural Economics, International Association of Agricultural Economists, 32(1), 21-41. doi: 10.1111/j.0169-5150.2004.00012.x. 
Gökırmaklı, Ç. ve Bayram, M. (2018). Gıda için gelecek öngörüleri: Yıl 2050. Akademik Gıda, 16(3), 351-360. doi: 10.24323/akademik-gida.475396.

Gündüz, A.Y. ve Kaya, M. (2007). Avrupa Birliği tarım politikası ve Türkiye’de organik tarımın geliştirilmesi üzerine olası etkisi. Elektronik Sosyal Bilimler Dergisi, 6(21), 305-330. Erişim adresi: https://dergipark.org.tr/tr/pub/esosder/issue/6135/82289.

Jebli, M. B. ve Youssef, S. B. (2015). The environmental Kuznets curve, economic growth, renewable and nonrenewable energy, and trade in Tunisia. Renewable and Sustainable Energy Reviews, 47, 173-185. doi: 10.1016/j.rser.2015.02.049.

Kan, A. (2019). Türkiye'de bölgesel düzeyde tarımsal üretim değeri, kadınların işgücüne katılımı ve sermaye stoku arasındaki ilişkinin panel veri analizi ile karşılaştırması. Türk Tarım ve Doğa Bilimleri Dergisi, 6(1), 52-63. doi: 10.30910/turkjans.515347.

Kılavuz, E. ve Erdem, İ. (2019). Dünyada tarım 4.0 uygulamaları ve Türk tarımının dönüşümü. Social Sciences, 14(4), 133-157. doi:10.12739/NWSA.2019.14.4.3C0189.

Lambert, D.K., Lim, S.H., Tweeten, K., Leistritz, F.L., Wilson, W.W., G.J. McKee, W.E., ... Saxowsky, D.M. (2006). An overview of agricultural value added in agricultural value added: Prospects for North Dakota. (Rapor No. AAE06008). North Dakota State University: Department of Agribusiness and Applied Economics.

Lampkin, N. (1990). Organic farming. Ipswich: Farming Press.

Lio, M., ve Liu, M-C. (2008). Governance and agricultural productivity: A cross-national analysis. Food Policy, 33(6), 504-512. doi:10.1016/j.foodpol.2008.06.003.

Lu, R. ve Dudensing, R. (2015). What do we mean by value-added agriculture?. Choices, Agricultural \& Applied Economics Association, 30(4), 1-8. doi:10.22004/ag.econ.229438

Menalled, F., Bass, T., Buschena, D., Cash, D., Malone, M., Maxwell, B., McVay, K., ...Weaver, D. (2008). An introduction to the principles and practices of sustainable farming. (Rapor No. MT200813AG). Montana State University: Agriculture and Natural Resources.

Olalı, H. ve Duymaz, İ. (1987). Tarımın Türk ekonomisindeki yeri ve ekonomik gelişmeye katkısı. İzmir: İzmir Ticaret Borsası Yayınları.

Olgun, A., Işın, Ş. ve Işın, F. (2018). Türkiye'de tarımsal GSYH ile tarımsal yatırımlar arasında nedensellik ilişkisi. Tarım Ekonomisi Dergisi, 4(1), 63-76. doi: 10.24181/tarekoder.450004.

Petek, A. ve Şanlı, O. (2019). Türkiye'de gayrisafi yurtiçi hasıla, döviz kurları ve sanayi üretim endeksinin kapasite kullanım oranları üzerine etkileri: Zaman serileri analizi. International Review of Economics and Management, 7(1), 49-73. https://dergipark.org.tr/tr/pub/iremjournal/issue/43337/435735.

Rizov, M., Pokrivcak, J. ve Ciaian, P. (2013). CAP (Common Agricultural Policy) subsidies and the productivity of EU farms. Journal of Agricultural Economics, 64(3), 537-557, doi: 10.1111/14779552.12030.

Soyyiğit, S. ve Yavuzaslan, K. (2019). Tarımsal katma değeri etkileyen faktörler üzerine bir inceleme: E7 ülkeleri örneği. Kafkas Üniversitesi İktisadi ve İdari Bilimler Fakültesi Dergisi (KAÜİIBFD), 10(19), 403-429. doi: 10.9775/kauiibfd.2019.017. 
Torres-Reyna, O. (2007). Panel data analysis fixed and random effects using stata. [Ders notları]. Data \& Statistical Services, Priceton University. Erişim adresi: https://www.academia.edu/34441090/Panel_Data_Analysis_Fixed_and_Random_Effects_using_Stat a_v_4_2.

Torun, İ. (2003). Endüstri toplumunun oluşmasında etkili olan iktisadi ve sina-i faktörler. Cumhuriyet Üniversitesi (C.Ü.) İktisadi ve İdari Bilimler Dergisi, 4(1), 181-196. Erişim adresi: http://eskidergi.cumhuriyet.edu.tr/makale/175.pdf.

\section{Extended Abstract}

\section{Purpose}

The aim of this study is to investigate the value-added agriculture and its determinants using the panel data analysis method with annual data of 20 selected countries for the period 2000-2018 obtained from the World Bank and Worldwide Governance Indicators websites. There are two questions in the study; "Can the determinants of value-added agriculture be determined by categorizing them into factors such as economic, social, political and legal?" and "How can gross domestic product per capita, gross fixed capital formation, agricultural labor ratio (\% of total labor force), urbanization rate ( $\%$ of total population), political stability and rule of law index can affect value-added agriculture?”.

\section{Design and Methodology}

2000-2018 period panel data analysis method was used to determine value-added agriculture and its determinants for 20 countries (Brazil, Turkey, France, the United States of America, Britain, Indonesia, Malaysia, Russia, Germany, China, Australia, India, South Africa, Italy, Spain, Japan, Mexico, Netherlands, Nigeria, Romania). The distinguishing feature of panel data is that it enables analysis of more realistic models, without including a time series / cross-section analysis. Hausman (1978) test is used which is frequently preferred within the scope of panel data analysis at the stage of model selection, and basically aims to determine the effects of unit or time and the correlation between independent variables. In panel regressions, two basic approaches are used: random effects (RE) model and fixed effects (FE) model. The fixed effects model reveals the observed change in the data over time. This model examines the relationship between dependent and independent variables discussed in the research. Units with certain qualifications (country, person and company etc.) can or cannot affect the predicted variables. In the random effects model, different results can be observed from the fixed effects model. The most important of these differences is that dependent and independent variables are not related to each other. The generalized method of moments estimators are based on the principle of equalization of sample and mass moments mean that the method of moments. The generalized moments method was proposed by Arellano and Bond (1991). In addition, the System and GMM estimator was developed by Arellano and Bover (1995). As a matter of fact; fixed effects model, random effects model, generalized moments method and system GMM and robust estimators econometric models are applied. As the determinants of A Panel Data Analysis of value-added agriculture (dependent variable); gross domestic product per capita, gross fixed capital formation, agricultural workforce rate (\% of total labor force), urbanization rate (\% of total population), political stability and rule of law index series (independent variables) are discussed. The variables related to the factors determining value-added agriculture were included in the analysis by taking their logarithms. 


\section{Findings}

In this study, dynamic GMM (Generalized Moments Method), System GMM, Fixed Effects, Random Effects and Robust (resistant error estimators) models developed by Arrellano \& Bond (1991) are used together in the estimation of factors determining value-added agriculture. In the study, these models for panel data analysis methods were used to determine the statistical significance and direction of the relationship between dependent and independent variables. When the Hausman test results are examined, it is seen that the probability value is Probe $>$ Chi square $=0.6692$. As a matter of fact, according to this table; it didn't yield a meaningful result that would reject the null hypothesis. Therefore, in this model, random effects model has been preferred. However, in order to understand the analysis more clearly; fixed effects, random effects and GMM (generalized method of moments) models were shown comparatively. According to the findings obtained as a result of the estimation; it was determined that there is a positive and significant relationship between value-added agriculture and GDP per capita. On the other hand, there is statistically significant and positive relationship between value-added agriculture and gross fixed capital formation. A positive and significant relationship was found between value-added agriculture and agricultural workforce ratio (\% of total labor force). A statistically significant and positive relationship has been found between value-added agriculture and urbanization rate (\% of total population). However, there is no relationship between valueadded agriculture and political stability indicator. In addition, a significant but negative relationship was found between value-added agriculture and the rule of law index. In this study, the statistical significance of the model was proved in accordance with the expectations.

\section{Research Limitations}

This study is limited to the time span indicated above because of the inability to access the data from official websites.

\section{Implications (Theoretical, Practical and Social)}

Although agriculture is an essential sector strategically, agricultural production is subject to natural conditions and these conditions come to the fore especially in terms of crop production. Due to the low ability to interfere with natural conditions, it is necessary to increase agricultural productivity by turning to areas that can be intervened within the scope of production conditions. Likewise, the level of meeting the production factors used for agricultural products (inputs such as labor, seed, fertilizer, machinery equipment and technology) from national resources has great importance in terms of determining the size of productivity and added value. In the study; the index series of per capita gross domestic product (GDP), gross fixed capital formation, agricultural labor force ( $\%$ of total labor force), urbanization rate ( $\%$ of total population), political stability and rule of law are taken as determinants factors of value-added agricultural. According to the analysis results; value-added agriculture has a positive and significant relationship with GDP per capita, gross fixed capital formation the agricultural labor force rate (\% of total labor force) and the rate of urbanization (\% of total population). The independent variable that has a significant but negative relationship with value-added agriculture is rule of law index. In addition, there was no statistically significant relationship between valueadded agriculture and political stability. In this study, it is seen that the model is statistically significant in accordance with the expectations. Value-added agriculture on the basis of countries is in an increasing trend with per capita GDP and this is maintained in the long term; it depends on increasing the production efficiency and improving the product quality for the use of mechanization and high technology in agriculture. In other words, investments in technology and digitalization that can increase value-added agriculture and / or productivity in countries should be supported. In order to increase the share of the total added value for the producer, not only incentives but also organizational policies should be developed. Finally, it should be noted 
that entrepreneurship and agro-tourism should be supported by directing qualified workforce to agricultural production.

\section{Originality/Value}

In terms of country selection, countries with different development levels and remarkable in terms of valueadded agriculture were generally preferred in this study. In the study, per capita gross domestic product (GDP), gross fixed capital formation, agricultural labor force ratio ( $\%$ of total labor force), urbanization rate ( $\%$ of total population), political stability and rule of law index series were taken as determinants of value-added agriculture. When considered from this point of view, the different and original aspect (original value) of the study from other studies is to determine the determinants of value-added agriculture on the basis of various variables used by categorizing it. In other studies in the literature have been made according to a single attribute (for example only on the economic aspect) without categorizing variables. The variables that value-added agriculture can be affected by; it has been handled in economic, social, political and legal framework. With the determination of the impressive power of these variables on value-added agriculture, it contributes to the economic growth by focusing on developments in the direction of increasing added value and correspondingly welfare of the country. At this point, it is thought that this study in which different dimensions have been evaluated is complementary to the other studies in the literature and make significant contributions to the theory.

Araştırmacı Katkısı: Zeynep ERDİNÇ (\%50), Gökçen AYDINBAŞ (\%50). 